\title{
Occurrence and characteristics of extended-spectrum $\beta$-lactamases producing Escherichia coli in foods of animal origin and human clinical samples in Chhattisgarh, India
}

\author{
Bhoomika ${ }^{1}$, Sanjay Shakya ${ }^{1}$, Anil Patyal ${ }^{1}$ and Nitin Eknath Gade ${ }^{2}$
}

1. Department of Veterinary Public Health and Epidemiology, College of Veterinary Science and Animal Husbandry, Chhattisgarh Kamdhenu Vishwa Vidyalaya, Anjora, Durg, Chhattisgarh, India; 2. Department of Veterinary Physiology and Biochemistry, College of Veterinary Science and Animal Husbandry, Chhattisgarh Kamdhenu Vishwa Vidyalaya, Anjora, Durg, Chhattisgarh, India.

Corresponding author: Sanjay Shakya, e-mail: shakyadurg@gmail.com, B: sirsant.mannat.09@gmail.com,AP: anilvet01@gmail.com, NEG: nitingadeivri@gmail.com Received: 29-03-2016, Accepted: 10-08-2016, Published online: 21-09-2016

doi: 10.14202/vetworld.2016.996-1000 How to cite this article: Bhoomika, Shakya S, Patyal A, Gade NE (2016) Occurrence and characteristics of extended-spectrum $\beta$-lactamases producing Escherichia coli in foods of animal origin and human clinical samples in Chhattisgarh, India, Veterinary World, 9(9): 996-1000.

\begin{abstract}
Aim: To assess the prevalence of antimicrobial resistance producing extended-spectrum $\beta$-lactamases (ESBL) (bla ${ }_{\text {TEM }}$, $b l a_{\mathrm{SHV}}$, and $\left.b l a_{\text {СТХ-М }}\right)$ genes in Escherichia coli isolated from chicken meat, chevon meat, raw milk, and human urine and stool samples collected from tribal districts of Chhattisgarh, viz., Jagdalpur, Dantewada, Kondagaon, and Kanker.

Materials and Methods: A total of 330 samples, comprising 98 chicken meat, 82 chevon meat, 90 raw milk, and 60 human urine and stool samples, were processed for isolation of E. coli. Isolates were confirmed biochemically and further tested against commonly used antibiotics to know their resistant pattern. The resistant isolates were tested for ESBL production by phenotypic method followed by characterization with molecular method using multiplex-polymerase chain reaction technique.

Results: Overall 57.87\% (191/330) samples were found positive for E. coli, which include 66.32\% (65/98) chicken meat, 46.34\% (38/82) chevon meat, 81.11\% (73/90) raw milk, and 25\% (15/60) human urine and stool samples. Isolates showed the highest resistance against cefotaxime (41.36\%) followed by oxytetracycline (34.03\%), ampicillin (29.31\%), cephalexin (24.60\%), cefixime (16.75\%), and ceftazidime (13.08\%). Phenotypic method detected 10.99\% (21/191) isolates as presumptive ESBL producers, however, molecular method detected 3.66\% (7/191), 2.09\% (4/191), and 0.00\% (0/191) prevalence of $b l a_{\mathrm{TEM}}, b l a_{\mathrm{CTX}-\mathrm{M}}$, and $b l a_{\mathrm{SHV}}$, respectively.

Conclusion: The present study indicates a high prevalence of E. coli in raw chicken meat, chevon meat, and milk due to poor hygienic practices. The antibiotic susceptibility test detected the presence of the resistance pattern against ESBL in $E$. coli isolated from raw chicken meat, chevon meat, milk, and also in human clinical samples is of great concern. The appearance of $E$. coli in the human food chain is alarming and requires adaptation of hygienic practices and stipulate use of antibiotics.
\end{abstract}

Keywords: $b l a_{\mathrm{TEM}}, b l a_{\mathrm{SHV}}$, bla $a_{\mathrm{CTX}-\mathrm{M}}$, Escherichia coli, extended-spectrum $\beta$-lactamases.

\section{Introduction}

Food-borne diseases remain a major public health problem across the globe. Moreover, the situation worsens in developing countries like India due to difficulties in securing optimal hygienic food handling practices. Most of the bacterial pathogens associated with human enteric illness originate from animals and can be transmitted directly from animals to humans or indirectly through foods of animal origin, contaminated water, etc. [1,2]. Among the genus Enterobacter, Escherichia coli is mainly responsible for causing diarrhea, hemolytic uremic syndrome, and

Copyright: Bhoomika, et al. Open Access. This article is distributed under the terms of the Creative Commons Attribution 4.0 International License (http://creativecommons.org/licenses/ by/4.0/), which permits unrestricted use, distribution, and reproduction in any medium, provided you give appropriate credit to the original author(s) and the source, provide a link to the Creative Commons license, and indicate if changes were made. The Creative Commons Public Domain Dedication waiver (http:// creativecommons.org/publicdomain/zero/1.0/) applies to the data made available in this article, unless otherwise stated. hemorrhagic colitis (HC) [3]. E. coli can contaminate the foods of animal origin, viz., raw milk, meat, and their products and contribute to human food-borne diseases and food spoilage. E. coli also causes nosocomial infections especially meningitis in infants. More than $85 \%$ of urinary tract infections are attributed to this organism [4]. Several strains of E. coli are recognized as important pathogens responsible for causing severe human diseases such as HC and hemolytic uremic syndrome [5].

Nowadays, curing bacterial infections in human and veterinary medicine is facing several problems due to increased antimicrobial resistance (AMR) in bacteria against the most of the antibacterial agents. The intensive use and, particularly, the misuse of antibiotics have led to the development and selection of resistant bacteria in different settings. One of the most important AMR mechanisms in Enterobacteriaceae family is production of extended-spectrum $\beta$-lactamase (ESBL) enzymes. According to Ambler 
classification, ESBL is divided into four main groups from A to D [6]. ESBL enzymes TEM, SHV, and CTX-M from Group A have been widely reported to be produced by $E$. coli. These enzymes can hydrolyze ampicillin, carbenicillin, oxacillin, and an extended spectrum of cephalosporins such as ceftazidime and cefotaxime [7].

The emergence of ESBL producing E. coli in the food-producing animals and in foods of animal origin is a growing problem worldwide [8]. There are scanty reports animals and on the association of ESBL producing enteric bacteria in humans and foods of animal origin in India as in the state of Chhattisgarh. Therefore, this study was conducted to investigate the occurrence of ESBL-producing E. coli in foods of animal origin and human clinical samples from different districts of Chhattisgarh, India.

\section{Materials and Methods}

\section{Ethical approval}

Live animals were not used in this study, so ethical approval was not necessary. Meat samples were collected from retail meat shops, and human clinical samples were collected from hospitals, private clinics, and diagnostic centers.

\section{Sample collection}

A total of 330 samples comprising of chicken meat, chevon meat, raw milk, and human urine and stool were collected randomly during August 2014 to July 2015 from Jagdalpur, Dantewada, Kanker, and Kondagaon districts of Chhattisgarh, India. The chicken meat $(n=98)$ and chevon meat $(n=82)$ samples were aseptically collected from retail meat shops and slaughter houses as per the guidelines of the International Commission on Microbiological Specifications for Foods [9]. Raw milk samples $(n=90)$ were aseptically collected from hotels/restaurants using sterile milk sample bottles. All milk samples were stored at $4{ }^{\circ} \mathrm{C}$ and were cultured within $5 \mathrm{~h}$. Human urine $(\mathrm{n}=56)$ and stool samples $(\mathrm{n}=4)$ were collected from hospitals, private clinics, and diagnostic centers. Human patients suffering from urinary tract infection were given dry test tube and requested to provide $10-20 \mathrm{ml}$ urine sample for examination. The human stool samples were collected using sterilized dry absorbent cotton swab following the protocol of Cheesbrough [10].

\section{Isolation and biochemical characterization}

Isolation was carried out as per method described by Agarwal et al. [11]. Briefly, $10 \mathrm{~g}$ of raw chicken and chevon meat, $1 \mathrm{ml}$ of raw milk, $1 \mathrm{~g}$ of human stool, and $1 \mathrm{ml}$ of human urine samples were taken and inoculated in sterilized MacConkey's lactose broth (HiMedia, India) and incubated at $37^{\circ} \mathrm{C}$ for $24 \mathrm{~h}$. Thereafter, a loop-full culture from enrichment broth was taken and streaked onto MacConkey's lactose agar (HiMedia, India) and incubated at $37^{\circ} \mathrm{C}$ for $24 \mathrm{~h}$. The suspected E. coli colonies, pink to red were picked up and further streaked on eosin methylene blue agar (HiMedia, India) and incubated at $37^{\circ} \mathrm{C}$ for $24 \mathrm{~h}$. Dark-centered and flat colonies with metallic sheen were considered as E. coli. All the E. coli isolates were further confirmed by indole, methyl red, Voges-Proskauer, and citrate utilization biochemical tests.

Antimicrobial susceptibility test and multiple antibiotic resistance (MAR) index

All biochemically confirmed E. coli isolates were tested for their antimicrobial drug susceptibility pattern on Mueller-Hinton agar (MHA) (HiMedia, India) by the disc diffusion method [12]. The antibiotics used were oxytetracycline $(30 \mu \mathrm{g})$, cephalexin $(30 \mu \mathrm{g})$, ciprofloxacin $(5 \mu \mathrm{g})$, gentamicin $(30 \mu \mathrm{g})$, cefotaxime $(10 \mu \mathrm{g})$, ampicillin $(10 \mu \mathrm{g})$, ceftazidime $(30 \mu \mathrm{g})$, aztreonam $(30 \mu \mathrm{g})$, imipenem $(10 \mu \mathrm{g})$, cefixime $(5 \mu \mathrm{g})$, and meropenem $(10 \mu \mathrm{g})$ (HiMedia, India). The diameter of the zones of complete inhibition was measured and compared with the zone size interpretation chart and was graded as sensitive, intermediate, and resistant. The MAR Index was also calculated for all $E$. coli isolates, by applying formula a/b where "a" is the number of antibiotics to which an isolate was resistant and "b" is the number of antibiotics to which the isolates exposed [13].

\section{Phenotypic detection of ESBL producers}

As per CLSI protocol, E. coli isolates with a zone of inhibition of $\leq 17 \mathrm{~mm}$ for aztreonam and ceftazidime, and $\leq 22 \mathrm{~mm}$ for cefotaxime in disc diffusion susceptibility testing were selected for detection of ESBLs production. For this purpose, four antibiotics cefotaxime $(10 \mu \mathrm{g})$, ceftazidime $(30 \mu \mathrm{g})$, aztreonam $(30 \mu \mathrm{g})$, and cefotaxime + clavulanic acid $(30+10 \mu \mathrm{g})$ (HiMedia, India) were used. Discs were placed on the inoculated MHA plates at a distance of $25 \mathrm{~mm}$ apart and incubated overnight. The E. coli isolates resistant to either of the cephalosporin discs and sensitive to their respective cephalosporin+clavulanic acid discs with diameter of more than $5 \mathrm{~mm}$ were considered as presumptive ESBL producers [13].

\section{Molecular characterization of ESBL-encoding genes}

All the presumptive ESBL producing E. coli isolates were screened for the detection of $b l a_{\mathrm{TEM}}, b l a_{\mathrm{SHV}}$, and $b l a_{\text {CTX-M }}$ genes by multiplex-polymerase chain reaction (m-PCR) as described by Monstein et al. [14] with some modifications. Template DNA incorporated in PCR reactions was prepared by boiling and snap chill method as outlined by Nagappa et al. [15]. Purity and concentration of DNA were detected by $0.8 \%$ agarose gel electrophoresis and stored at $-20^{\circ} \mathrm{C}$. The recommended oligonucleotide primers specific for the $b l a_{\mathrm{SHV}}[16], b_{\mathrm{TEM}}[14]$, and bla $a_{\mathrm{CTX}-\mathrm{M}}[17]$ genes used in the m-PCR assay and expected amplicon sizes are given in Table-1. All the primers used in the present study were procured from the Imperial Life Sciences (P) Limited, Gurgaon, Haryana, India. PCR reactions were performed in a total volume of $25 \mu 1$ containing $\times 10$ PCR buffer (Tris with $15 \mathrm{mM} \mathrm{MgCl}_{2}$ ), $25 \mu \mathrm{M}$ 
of each deoxyribonucleotide triphosphate, $10 \mathrm{pmol}$ of each gene-specific primers, $1 \mathrm{U}$ Taq polymerase, and $3 \mu \mathrm{l}$ of template DNA. The m-PCR was done using thermocycler (Mastercycler, Eppendorf, Germany), and cycles were performed with initial denaturation of $95^{\circ} \mathrm{C}$ for $10 \mathrm{~min} ; 30$ cycles of denaturation at $94^{\circ} \mathrm{C}$ for 30 seconds, annealing at $60^{\circ} \mathrm{C}$ for $30 \mathrm{~s}$, extension at $72^{\circ} \mathrm{C}$ for 2 min followed by a final extension step at $72^{\circ} \mathrm{C}$ for $10 \mathrm{~min}$. After the completion of reaction cycles, the amplified products were electrophoresed on $1.5 \%$ agarose gel and stained with $0.5 \mu \mathrm{g} / \mathrm{ml}$ ethidium bromide. The images of ethidium bromide stained DNA bands were analyzed under UV transilluminator (Biometra) and recorded using a Gel Documentation System (Gel Doc ${ }^{\mathrm{TM}} \mathrm{XR}$, Biorad, USA).

\section{Results and Discussion}

In the present study, a total of 191 (57.87\%) isolates were identified as E. coli after morphological and biochemical characterization. The highest prevalence of $E$. coli was observed in raw milk samples followed by chicken meat, chevon meat, and human urine and stool samples (Table-2). In chicken meat samples, $66.32 \%$ prevalence of $E$. coli was recorded which is comparable with the findings of Patyal et al. [18], who reported $68 \%$ prevalence rate in Jaipur, Rajasthan. Similarly, Sharma and Bist [19] also reported 70\% prevalence rate in chicken meat in Mathura city of Uttar Pradesh. However, lower prevalence rates of $40 \%$ were reported by Rashid et al. [20] in Jammu.

Table-1: Detail of the primers used in $\mathrm{m}-\mathrm{PCR}$ amplification.

\begin{tabular}{llc}
\hline $\begin{array}{l}\text { Target } \\
\text { gene }\end{array}$ & Primer sequence & $\begin{array}{c}\text { Amplicon } \\
\text { size (bp) }\end{array}$ \\
\hline$b l a_{\text {SHV }}$ & ATG CGT TAT ATT CGC CTG TG & 747 \\
$b l a_{\text {TEM }}$ & TGC TTT GTT ATT CGG GCC AA & \\
& TCG CCG CAT ACA CTA TTC & 445 \\
& TCA GAA TGA & \\
& ACG CTC ACC GGC TCC AGA & \\
$b l a_{\text {CTX-M }}$ & TT AT & 593 \\
& ATG TGC AGY ACC AGT AAR & \\
& GTK ATG GC & \\
& TGG GTR AAR TAR GTS ACC \\
\hline
\end{tabular}

$\mathrm{m}-\mathrm{PCR}=$ Multiplex-polymerase chain reaction
During the present study, $46.34 \%$ chevon meat samples were found positive for E. coli. The level of contamination was significantly lower as compared to reports of Gangil et al. [21], who recorded 76\% prevalence in chevon meat in Jaipur, Rajasthan, India, and on contrary, lower prevalence rates of $16.66 \%$ by Panda et al. [22] in Palam valley, Uttarakhand, India; 35\% by Ahmad et al. [23] in Lahore, Pakistan; $38.09 \%$ by Dewangan [24] in Chhattisgarh, India, were reported. In milk samples, $81.1 \%$ prevalence of E. coli was recorded, which is lower than previously reported prevalence rates of $100 \%$ by Rai et al. [25] in Dehradun city, Uttarakhand, India. However, lower prevalence rates of $33.96 \%$ and $32.93 \%$ were reported by Rashid et al. [20] in Jammu and Kashmir, India, and Gautam et al. [26] in Allahabad, UP, India, respectively. The $25 \%$ prevalence of $E$. coli in human stool and urine samples was recorded in the present study, which is comparable with the findings of Rajan and Prabavathy [27], who reported 20.46\% prevalence rate in urine samples in community hospital of Chennai, Tamil Nadu, India. Whereas, higher prevalence rates of $32.5 \%$ and $59 \%$ were reported by Kumar et al. [28] and Virpari et al. [29] in Anand city, Gujarat, India. Kumar et al. [30] in Greater Noida and Xavier et al. [31] in Tamil Nadu, reported lower prevalence rates of $3.88 \%$ and $15 \%$, respectively, in human stool sample.

Antimicrobial susceptibility test showed that $41.36 \%$ isolates were resistant to cefotaxime followed by oxytetracycline $(34.03 \%)$, ampicillin $(29.31 \%)$, cephalexin $(24.60 \%)$, cefixime $(16.75 \%)$, and ceftazidime (13.08\%). A similar type of observations was also recorded by Rashid et al. [20], who reported that $40 \% \mathrm{E}$. coli isolates were resistant to cefotaxime. Among 191 E. coli isolates, 74 isolates were resistant for two or more than two antibiotics. The highest MAR of 0.9 was recorded in one isolate, followed by 0.81 by 2 isolates, 0.72 by 2 isolates, 0.63 by 2 isolates, 0.54 by 13 isolates, 0.45 by 10 isolates, 0.36 by 8 isolates, 0.27 by 12 isolates, and 0.18 by 24 isolates. 57 isolates were resistant to single antibiotic representing 0.09 MAR index. On contrary, 60 isolates were completely sensitive for all antibiotics. The prevalence of MAR in E. coli isolates was also

Table-2: Prevalence of E. coli and bla ${ }_{\mathrm{TEM}}$ bla ${ }_{\mathrm{CTX}-\mathrm{M}}$ and bla ${ }_{\mathrm{SHV}}$ gene in chicken meat, chevon meat, milk, and human clinical samples.

\begin{tabular}{|c|c|c|c|c|c|c|}
\hline \multirow{3}{*}{$\begin{array}{l}\text { Types of } \\
\text { sample }\end{array}$} & \multirow{3}{*}{$\begin{array}{c}\text { Number } \\
\text { of } \\
\text { samples } \\
\text { collected }\end{array}$} & \multirow{3}{*}{$\begin{array}{c}\text { Number } \\
\text { of positive } \\
\text { samples (\%) }\end{array}$} & \multicolumn{4}{|c|}{ ESBL production (\%) } \\
\hline & & & \multirow{2}{*}{$\begin{array}{l}\text { Phenotypic } \\
\text { method }\end{array}$} & \multicolumn{3}{|c|}{ Molecular method } \\
\hline & & & & bla $_{\text {TEM }}$ & $\boldsymbol{b l a}_{\mathrm{CTX}-\mathrm{M}}$ & bla $_{\text {SHV }}$ \\
\hline Chicken meat & 98 & $65(66.32)$ & $2(3.07)$ & $1(1.53)$ & $1(1.53)$ & 0 \\
\hline Chevon meat & 82 & $38(46.34)$ & $7(18.42)$ & $1(2.63)$ & $0(0.00)$ & 0 \\
\hline Raw milk & 90 & $73(81.11)$ & $9(12.32)$ & $4(5.47)$ & $2(2.73)$ & 0 \\
\hline $\begin{array}{l}\text { Human urine } \\
\text { and stool } \\
\text { samples }\end{array}$ & $60(56+4)$ & $15(25)$ & $3(20)$ & $1(6.66)$ & $1(6.66)$ & 0 \\
\hline Total & 330 & $191(57.87)$ & 21 (10.99) & $7(3.66)$ & $4(2.09)$ & $0(0.00)$ \\
\hline
\end{tabular}

E. coli=Escherichia coli, ESBL=Extended-spectrum $\beta$-lactamases 
reported by Krumperman [13] and Jaulkar et al. [32]. The pathogens with higher indices of MAR in foods of animal origin may possibly be introduced from the environment. The wide use and abuse of antibiotic in mass production of livestock has promoted the emergence of MAR E. coli in animals. MAR E. coli isolates were rarely found among animals, in which antibiotics are seldom or never used [13].

Out of 191 E. coli isolates, $21(10.99 \%)$ were phenotypically identified as presumptive ESBL producers. Among 21 isolates, 9 (12.32\%), 7 (18.42\%), 2 (3.07), and $3(20 \%)$ isolates were from milk, chevon meat, chicken meat, and human urine and stool samples, respectively (Table-2). Rasheed et al. [33] reported $12.5 \%$ ESBL producer isolates by phenotypic method in chicken meat which is in accordance to the present findings. The genotypic methods help us to confirm the presence of genes in E. coli isolates which are responsible for ESBL production. Out of 21 E. coli presumptive ESBL producers, seven isolates expressed either one or two genes in m-PCR. The overall prevalence of $b l a_{\mathrm{TEM}}$ and $b l a_{\text {СTХ-M }}$ genes among $E$. coli isolates recorded was $3.66 \%$ and $2.09 \%$, respectively. The prevalence rate of $b l a_{\text {TEM }}$ gene among chevon meat, chicken meat, milk, and human clinical isolates were $2.63 \%, 1.53 \%, 5.47 \%$, and $6.66 \%$, respectively. The prevalence rate of bla $a_{\text {Стх-м }}$ gene in milk, chevon meat, and clinical samples were $2.73 \%(2 / 73), 1.53 \%(1 / 65)$, and $6.66 \%(1 / 15)$, respectively (Table-2). 2 milk and 1 chevon $E$. coli isolates displayed expression of $b l a_{\text {TEM }}$ gene only and 2 milk, 1 chicken meat, and 1 stool isolates were harbored both $b l a_{\mathrm{TEM}}$ and $b l a_{\mathrm{CTX}-\mathrm{M}}$ genes, whereas none of the isolates expressed the $b l a_{\mathrm{SHV}}$ gene (Figure-1). Similarly, Apaka et al. [34] also reported a higher prevalence of $b l a_{\text {ТЕм }}$ gene $(100 \%)$ than bla $_{\text {СтХ-м }}$ $(37.5 \%)$ bla $_{\mathrm{SHV}}(4.1 \%)$ gene. Amplification of whole genomic DNA increased the possibility of detection, compared to the amplification of plasmid DNA alone, suggesting beta-lactamase expression is controlled by both chromosomal and plasmids DNA. Sometimes, multiple genes are responsible for the production of

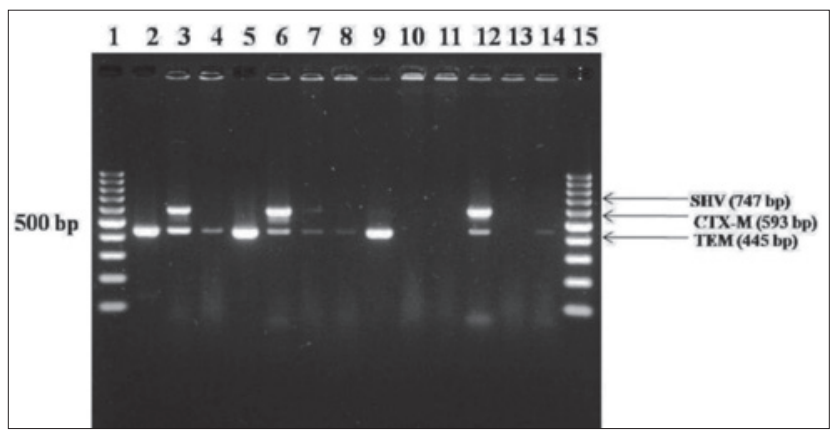

Figure-1: Escherichia coli isolates from foods of animal origin (chicken meat, chevon meat, and raw milk), human urine and stool samples showing resistance against extended-spectrum $\beta$-lactamases antibiotic by multiplexpolymerase chain reaction. Lane 1 and 15: 100 bp ladder, Lane 2 and 5: Positive control, Lane 3, 6, 7, 12: Positive for bla $a_{\mathrm{TEM}}$ and bla ${ }_{\mathrm{CTX}-\mathrm{M}}$ genes, Lane 4, 9, 14: Positive for bla ${ }_{\mathrm{TEM}}$ gene, Lane $10,11,13$ : Negative $E$. coli isolates.
ESBL in single isolates. Thus, the m-PCR was used for detection of two or more genes simultaneously in a single isolate. This method provided an efficient, rapid differentiation of ESBL in selected species of Enterobacteriaceae and provided an efficient, rapid screening of large number of isolates, and could be used as a rapid tool for epidemiological studies among ESBL isolates.

\section{Conclusion}

The overall prevalence of $E$. coli in chicken meat, chevon meat, milk, and human clinical samples was found $57.87 \%$. The study reveals that meat and milk samples are frequently contaminated with antimicrobial resistant bacteria due to the intensive use of antimicrobial agents in animal husbandry and dairy sector. ESBL producing E. coli strains were also isolated chicken meat, chevon meat, milk, and human clinical samples. The m-PCR assay confirmed that $3.66 \%$ isolates were harbored the $b l a_{\text {TEM }}$ gene and $2.09 \% b l a_{\text {CTX-M }}$ gene. These multidrug-resistant and ESBL producing E. coli strains can be transmitted to the human population after consumption of meat, milk, and their products. The appropriate antibiotic policy and infection control strategy in hospital settings are crucial to overcome the problems associated with infections by ESBL producing strains in humans. Thus, there is need for continued monitoring and surveillance of antimicrobial-resistant and ESBL producing $E$. coli at different levels, viz., animals, human and environment, and factors that contribute to their emergence and spread.

\section{Authors' Contributions}

SS designed and planned this research work. B collected the samples and executed the isolation, biochemical, molecular characterization work and carried out the antibiotic sensitivity assay of all isolates. AP analyzed the data and monitored the isolation, biochemical characterization, and antibiotic sensitivity assay. AP and NEG were involved in the molecular characterization experiment. All authors contributed equally in preparation and revision of the manuscript. All authors read and approved the final manuscript.

\section{Acknowledgments}

The authors are highly thankful to the Dean, College of Veterinary Science and Animal Husbandry, Chhattisgarh Kamdhenu Vishwa Vidyalaya, Anjora, Durg, Chhattisgarh, India, for providing necessary financial assistance and instrumentation facilities to carry out this research work.

\section{Competing Interests}

The authors declare that they have no competing interests.

\section{References}

1. Schlundt, J., Toyofuku, H., Jansen, J. and Herbst, S.A. (2004) Emerging food-borne zoonoses. Rev. Sci. Technol., 23(2): 513-533. 
2. Newell, D.G., Koopmans, M., Verhoef, L., Duizer, E., Aidara-Kane, A., Sprong, H., Opsteegh, M., Langelaar, M., Threfall, J., Scheutz, F., Van Der Giessen, J. and Kruse, H. (2010) Food borne diseases the challenges of 20 years ago still persist while new ones continue to emerge. Int. J. Food Microbiol., 139: 3-15.

3. Lanjewar, M., De, A. and Mathur, M. (2010) Diarrheogenic E. coli in hospitalized patients: Special to Shiga like toxin producing Escherichia coli. Indian J. Pathol. Microbiol., 53(1): 75-78.

4. Struelens, M.J., Denis, O. and Villalobos, H.R. (2004) Microbiology of nosocomial infections: Progress and challenges. Microbes Infect., 6(11): 1043-1048.

5. Ferens, W.A. and Hovde, C.J. (2011) Escherichia coli O157:H7: Animal reservoir and sources of human infection. Foodborne Pathog. Dis., 8(4): 465-487.

6. Jacoby, A.G. and Munoz-Price, L.S. (2005) Mechanisms of disease the new beta lactamase. N. Engl. J. Med., 325: 380-391.

7. Paterson, L.D. and Bonomo, A.R. (2005) Extended spectrum beta lactamase: A clinical update. Clin. Microbiol. Rev., 18(4): 657-686.

8. Geser, N., Stephan, R. and Hachler, H. (2012) Occurrence and characteristics of extended- spectrum b-lactamase (ESBL) producing enterobacteriaceae in food producing animals, minced meat and raw milk. B.M.C. Vet. Res., 8: 21-29.

9. International Commission on Microbiology Specification for Foods (ICMSF). (1978) Microorganisms in Food. $2^{\text {nd }}$ ed. University of Toronto Press, Canada. p115-118.

10. Cheesbrough, M. (2006) District Laboratory Practice in Tropical Countries - Part-2. Cambridge University, New York, USA. p184-186.

11. Agarwal, R.K., Bhilegaonkar, K.N., Singh D.K., Kumar, A. and Rathore, R.S. (2003) Laboratory Manual for the Isolation and Identification of Food Borne Pathogens. $1^{\text {st }}$ ed. ICAR Publication, New Delhi.

12. CLSI. (2012) Performance Standards for Antimicrobial Susceptibility Testing: Twenty Second Informational Supplement. M100-S22. Clinical and Laboratory Standards Institute, Wayne, PA, USA

13. Krumperman, P.H. (1983) Multiple antibiotic resistance indexing of Escherichia coli to identify high-risk sources of faecal contamination of foods. Appl. Environ. Microbiol., 46(1): 165-170.

14. Monstein, H.J., Ostholm-Balkhed, A., Nilsson, M.V., Dornbusch, K. and Nilsso, L.E. (2007) Multiplex PCR amplification assay for rapid detection of bla $_{\mathrm{SHY}}$, bla $_{\mathrm{TEM}}$ and bla $_{\text {СTX-M }}$ genes in enterobacteriaceae. A.P.M.I.S., 115(1): 400-408

15. Nagappa, K., Tamuly, S., Brajmadhuri, Saxena, M.K. and Singh, S.P. (2007) Isolation of Salmonella Typhimurium from poultry eggs and meat of Tarai region of Uttaranchal. Indian J. Biotechnol., 6: 407-409.

16. Paterson, D.L., Hujer, K.M., Hujer, A.M., Yeiser, B. and Bonomo, M.D. (2003) Extended spectrum b- lactamases in Klebsiella pneumoniae blood stream isolates from seven countries: Dominance and widespread prevalence of SHV-and CTX-M-type b-lactamases. Antimicrob. Agents Chemother., 47(11): 3553-3560.

17. Boyd, D.A., Tyler, S., Christianson, S., McGeer, A. and Muller, M.P. (2004) Complete nucleotide sequence of a 92-kilobase plasmid harbouring the CTX-M-15 extended-spectrum beta-lactamase involved in an outbreak in long-term-care facilities in Toronto, Canada. Antimicrob. Agents Chemother., 48(10): 3758-3764.

18. Patyal, A., Gangil, R., Singh, P.K., Mathur, K.N. and Sudan, V. (2012) Bacteriological quality of market chicken meat in Jaipur city. J. Vet. Public Health, 10(1): 45-48.
19. Sharma, I. and Bist, B. (2010) Antibiotic resistance in Escherichia coli isolated from raw goat, pig and poultry meat in Mathura city of Northern India. Assam Univ. J. Sci. Technol. Biol. Environ. Sci., 6(1): 89-92.

20. Rashid, M., Kotwal, S.K., Malik, M.A. and Singh, M. (2013) Prevalence, genetic profile of virulence determinants and multidrug resistance of Escherichia coli isolates from foods of animal origin. Vet. World, 6(3): 139-142.

21. Gangil, R., Patyal, A. and Mathur, K.N. (2011) Microbiological quality of marketable raw goat meat in Jaipur city and its public health significance. J. Vet. Public Health, 9(1): 63-64.

22. Panda, A.K., Kumar, A., Thakur, S.D. and Shalmali. (2012) Evaluation of bacteriological quality of raw meat and meat products in Palam valley of North Western Himalayas. J. Vet. Public Health, 10(1): 21-25.

23. Ahmad, M.U.D., Sarwar, A., Najeeb, M.I., Nawaz, M., Anjum, A.A., Ali, M.A. and Mansur, N. (2013) Assessment of microbial load of raw meat at abattoirs and retail outlets. J. Anim. Plant Sci., 23(3): 745-748

24. Dewangan, P. (2014) Studies on prevalence of E. coli with special reference to multidrug resistant strains of public health significance in foods of animal origin. M.V.Sc. Thesis Submitted in Department of Veterinary Public Health and Epidemiology, College of Veterinary Science and Animal Husbandry, Anjora, Durg, Chhattisgarh.

25. Rai, N., Pant, R. and Nirwal, S. (2013) Prevalence of antibiotic resistant bacteria and analysis of microbial quality of raw milk samples collected from different regions of Dehradun. Int. J. Pharmacol. Tech. Res., 5(2): 804-810.

26. Gautam, A., Shukla, S., Ramteke, P.W. and Chandra, R. (2015) Studies on incidence and antibiotic susceptibility pattern of bacterial pathogens in dairy products. Pharm. Innov. J., 4(2): 69-72.

27. Rajan, S. and Prabavathy, J. (2012) Antibiotic sensitivity and phenotypic detection of ESBL producing E. coli Strains causing urinary tract infection in a community hospital, Chennai, Tamil Nadu, India. Webmedcentral Pharm. Sci., 3(11): 1-15.

28. Kumar, A., Verma, A.K., Malik, S., Gupta, M.K., Sharma, A. and Rahal, A. (2014 a) Occurrence of extended spectrum Beta-lactamases producing alpha hemolytic Escherichia coli in neonatal diarrhoea. Pak. J. Biol. Sci., 17(1): 109-113.

29. Virpari,P.K., Nayak, J.B., Thaker,H.C. andBrahmbhatt,M.N. (2013b) Isolation of pathogenic Escherichia coli from stool samples of diarrhoeal patients with history of raw milk consumption. Vet. World, 6(9): 659-663.

30. Kumar, D., Singh, A.K., Ali, M.R. and Chander, Y. (2014b) Antimicrobial susceptibility profile of extended spectrum $\beta$-lactamase (ESBL) Producing Escherichia coli from various clinical samples. Infect. Dis. Res. Treat., 7: 1-8.

31. Xavier, T.F., Auxilia, A. and Kannan, M. (2015) Isolation and characterization of UTI pathogens from HIV positive patients of Karur District, Tamil Nadu, India. Int. J. Curr. Microbiol. Appl. Sci., 4(1): 558-563.

32. Jaulkar, A.D., Zade, N.N., Katre, D.D., Khan, D.D., Chaudhary, S.P. and Shinde, S.V. (2011) Plasmid characterization of Salmonella isolated from foods of animal origin. J. Vet. Public Health, 9(1): 25-28.

33. Rasheed, M.U., Thajuddin, N., Ahamed, P., Teklemariam, Z. and Jamil, K. (2014) Antimicrobial drug resistance in strains of Escherichia coli isolated from food sources. Rev. Inst. Med. Trop. Sao Paulo, 56(4): 341-346.

34. Apaka, P.E., Legall, B. and Padman, J. (2010) Molecular detection and epidemiology of extended spectrum beta-lactamase genes prevalent in clinical isolates of Klebsiella pneumonae and E. coli from Trinidad and Tobago. West Indian Med. J., 59(6): 591-596. 